\title{
ER $\beta$ Binds N-CoR in the Presence of Estrogens via an LXXLL-like Motif in the N-CoR C-terminus
}

\author{
Paul Webb*1, Cathleen Valentine ${ }^{1,2}$, Phuong Nguyen ${ }^{1}$, Richard H Price Jr ${ }^{1,2}$, \\ Adhirai Marimuthu ${ }^{1}$, Brian L West ${ }^{1}$, John D Baxter ${ }^{1}$ and Peter J Kushner ${ }^{1,2}$
}

\begin{abstract}
Address: ${ }^{1}$ Metabolic Research Unit and Diabetes Center, University of California, San Francisco, CA 94143, USA and ${ }^{2}$ Department of Medicine, University of California, San Francisco, CA 94143, USA

Email: Paul Webb* - webbp@itsa.ucsf.edu; Cathleen Valentine - valentin@medicine.ucsf.edu; Phuong Nguyen - pnguyen@diabetes.ucsf.edu; Richard H Price - rhprice@itsa.ucsf.edu; Adhirai Marimuthu - amarimuthu@plexxikon.com; Brian L West - bwest@plexxikon.com; John D Baxter - JBaxter918@aol.com; Peter J Kushner - kushner@itsa.ucsf.edu

* Corresponding author
\end{abstract}

Published: 28 June 2003

Nuclear Receptor 2003, I:4

This article is available from: http://www.nuclear-receptor.com/content/l/l/4

(C) 2003 Webb et al; licensee BioMed Central Ltd. This is an Open Access article: verbatim copying and redistribution of this article are permitted in all media for any purpose, provided this notice is preserved along with the article's original URL.
Received: 13 May 2003

Accepted: 28 June 2003

\begin{abstract}
Nuclear receptors (NRs) usually bind the corepressors N-CoR and SMRT in the absence of ligand or in the presence of antagonists. Agonist binding leads to corepressor release and recruitment of coactivators. Here, we report that estrogen receptor $\beta$ (ER $\beta)$ binds N-CoR and SMRT in the presence of agonists, but not antagonists, in vitro and in vivo. This ligand preference differs from that of ER $\alpha$ interactions with corepressors, which are inhibited by estradiol, and resembles that of ER $\beta$ interactions with coactivators. ER $\beta / N-C o R$ interactions involve ER $\beta$ AF-2, which also mediates coactivator recognition. Moreover, ER $\beta$ recognizes a sequence (PLTIRML) in the N-CoR Cterminus that resembles coactivator LXXLL motifs. Inhibition of histone deacetylase activity specifically potentiates ER $\beta$ LBD activity, suggesting that corepressors restrict the activity of AF-2. We conclude that the ER isoforms show completely distinct modes of interaction with a physiologically important corepressor and discuss our results in terms of ER isoform specificity in vivo.
\end{abstract}

\section{Background}

The nuclear receptor (NR) family comprises 48 structurally related transcription factors, many of which require their cognate ligand for activity [1-3]. The NRs regulate transcription by binding to response elements in the promoters of target genes and acting as scaffolds for the assembly of large coactivator and corepressor complexes [4]. NR coactivators include the p160s (including GRIP1/ TIF-2, SRC-1 and AIB1/ACTR/pCIP). The p160s enhance transcription by binding histone acetyl-transferases such as p300/CBP and pCAF [5] and methyl-transferases such as CARM1 and PRMT [6] which, in turn, enhance transcription by modification of chromatin. Other NR coacti- vators include TRAP220[7], which is part of a larger complex (TRAP/DRIP/SMCC/mediator) that contacts the basal transcription machinery and PGC-1[8], a cold inducible coactivator that binds CBP and SRC- 1 and proteins involved in RNA processing [9]. NR corepressors include NR corepressor ( $\mathrm{N}$-CoR) and silencing mediator of retinoid and thyroid responsive transcription (SMRT) [4]. Both N-CoR and SMRT repress transcription, at least in part, by binding to histone de-acetylases (HDACs) either directly or indirectly through other corepressor complex components. Other known NR corepressors include RIP140 [10], Hairless [11], short heterodimer partner (SHP) [12] and DAX [13], and receptor specific 
corepressors such as the estrogen receptor (ER) interacting proteins REA and HET-SAFB [14,15].

Generally, NR transcriptional activity is dictated by the balance between coactivator and corepressor recruitment, and one of the most important factors that influences this balance is the absence or presence of agonist ligands (reviewed in [4]). Unliganded NRs such as thyroid (TRs) and retinoid receptors (RARs) bind corepressors, and ligand promotes release of corepressor and subsequent binding of coactivators. The mechanism of this coregulator exchange is well understood. NRs consist of three domains, the N-terminal domain (which contains a context-specific activation function AF-1), the central DNA binding domain (DBD) and the C-terminal ligand binding domain (LBD), which contains a hormone-dependent activation function, AF-2. The unliganded LBD recognizes hydrophobic motifs, termed interaction domains (IDs), which are reiterated three times in $\mathrm{N}-\mathrm{CoR}$ and twice in SMRT and conform to the consensus L/IXXIIXXXL [4](see also[16]). By contrast, the liganded LBD binds shorter hydrophobic motifs termed NR boxes that are reiterated several times within each coactivator and conform to the consensus LXXLL. The LBD utilizes a large hydrophobic cleft composed of residues along H3 and $\mathrm{H} 5$ to bind IDs [17], and a smaller hydrophobic cleft that is composed of residues in the upper part of $\mathrm{H} 3$ and $\mathrm{H} 5$ and $\mathrm{H} 12$ (and corresponds to AF-2) to bind NR boxes [18]. Thus, agonists promote coregulator exchange by promoting the packing of $\mathrm{H} 12$ over the lower part of the ID binding region, an event that simultaneously completes the coactivator binding surface. In other cases, however, the balance of coactivator and corepressor recruitment is regulated by direct competition for the AF-2 surface, rather than ligand-dependent coregulator exchange. RIP140, Hairless and DAX possess NR boxes that interact with AF-2 $[11,13,19]$ and these corepressors act as negative regulators of the activity of the liganded NR.

The NR family contains two related ERs (ER $\alpha$ and ER $\beta$ ) that conform to the typical three domain NR structure and share extensive sequence homology in the DBD and LBD region[20,21]. Analysis of the function of the individual ERs in mouse knockout models suggests that the major proliferative effects of estrogen are mediated by ER $\alpha$ and not by ER $\beta$, which seems to play an inhibitory role in proliferation in some studies[22,23]. The ligand-binding properties of the ERs are different, with ER $\beta$ often exhibiting stronger binding to plant-derived phytoestrogens [24]. More importantly, the ERs exhibit isoform-specific effects on gene expression. Both ERs enhance transcription from genes with classical estrogen response elements (EREs), but ER $\alpha$ requires less ligand to obtain maximal activation than $\operatorname{ER} \beta[25,26]$. Likewise, both ERs suppress the activity of the TNF $\alpha$ promoter in response to estro- gens, but ER $\beta$ is a more potent repressor than ER $\alpha$ [27]. However, some of the most striking isoform-specific differences in gene regulation are observed at promoters, such as that of cyclin D1, which contain AP-1 sites or related cyclic AMP response elements (CREs). ER $\alpha$ enhances AP-1 activity in response to estrogens, $[28,29]$ but ER $\beta$ inhibits AP- 1 activity in response to estrogens [29-31]. ER $\beta$ also completely suppresses ER $\alpha$ activity at the cyclin D1 promoter and even suppresses the activity of an ER $\alpha$ mutant that is selectively superactive at AP-1 sites and CREs [29]. Finally, ER $\beta$ shows a unique capacity to enhance AP-1 activity in response to selective estrogen receptor modulators (SERMs) such as raloxifene, tamoxifen and ICI 182,780/Faslodex (ICI) [30-32]. Together, these observations suggest that there are fundamental differences in the way that the ERs bind unspecified cofactors that modulate gene expression, and that some of these cofactors must play a role in differential ER activity at AP-1 sites.

Although the poorly conserved NTD region clearly plays an important role in isoform-specificity [32,33], it is also likely that there are differences in the better conserved LBD region that contribute to differential ER $\alpha$ and ER $\beta$ activities. Phage display techniques have revealed that ER $\alpha$ and ER $\beta$ show different preferences in LXXLL binding (reviewed in $[34,35]$ ). Moreover, some cofactors that contain LXXLL motifs show differential binding to LBDs of the ER isoforms (reviewed in [36]). SHP binds ER $\alpha$ preferentially [37], and represses ER $\alpha$ activity more strongly than that of ER $\beta$. The PGC- 1 related protein PERC also binds ER $\alpha$ preferentially, and potentiates ER $\alpha$ activity more strongly than that of ER $\beta$ [38]. We recently observed that $\mathrm{ER} \alpha$ binds the C-terminal NR interacting regions of $\mathrm{N}$-CoR and SMRT in the presence of SERMs but not estrogens [39]. In this study, we report that ER $\beta$ interactions with N-CoR and SMRT are promoted by agonists and inhibited by SERMs. Thus, the ERs show completely opposite ligand preferences of interaction with corepressors. We discuss the potential significance of these different modes of ER interaction with N-CoR in terms of known isoform-specific behaviors.

\section{Results \\ Agonist Dependent ER $\beta$ Interactions with $\mathrm{N}-\mathrm{Co} R$ and SMRT}

To investigate ER $\beta$ interactions with corepressors, we examined the interactions of full length ER $\beta$ (amino acids $1-530$ ) with bacterially expressed C-terminal NR interacting domain of $\mathrm{N}-\mathrm{CoR}$ (amino acids 1944-2453) in vitro (Fig. 1A). Fig. 1B reveals, surprisingly, that ER $\beta$ bound N$\mathrm{CoR}$ in the absence of hormone and in the presence of agonist ligands (E2, DES) and phytoestrogens (genistein, coumestrol). Moreover, these interactions were suppressed by SERMs (ICI, raloxifene and tamoxifen). ER $\beta$ 
A
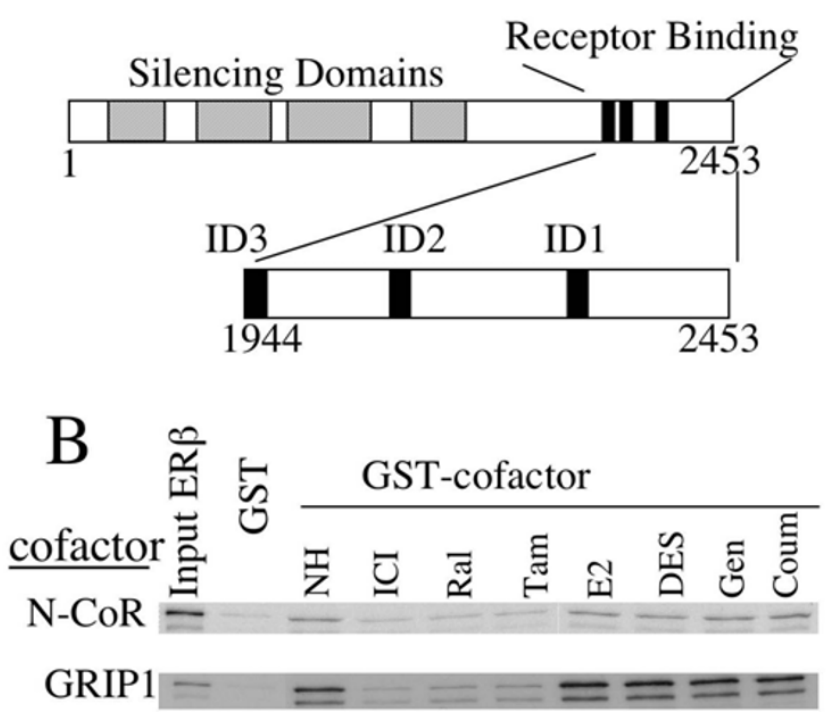

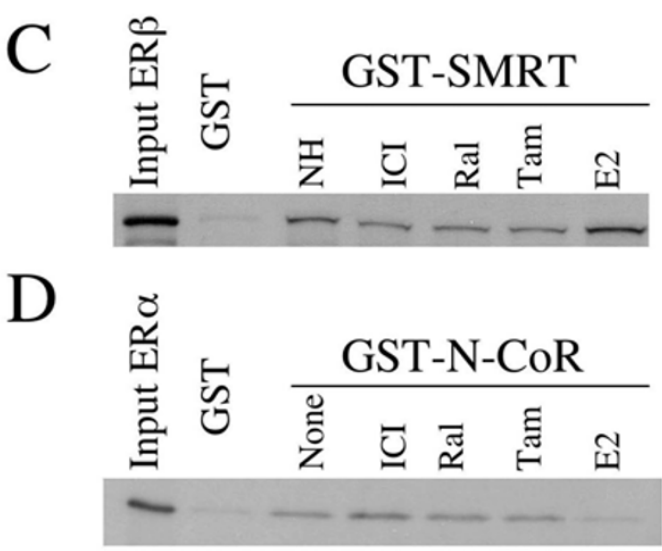

E
GST- GST-

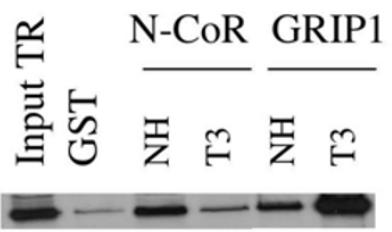

Figure I

ER $\beta$ Binds N-CoR in the Presence of Agonists. (A) Schematic of N-CoR primary structure. Silencing domains are indicated with hatched bars. NR binding regions (ID motifs) are illustrated with solid bars. (B) Radiolabeled ER $\beta$ retained by GST-NCoR (amino acids 1944-2453) or GST-GRIPI (amino acids 563-II2I) after separation by SDS-PAGE. The amounts of bound proteins are compared to $10 \%$ of the input protein used in the binding assay in this experiment, and all results shown in the paper. (C) Radiolabeled ER $\beta$ retained by GST SMRT (amino acids 987-I49I). (D) Radiolabeled ER $\alpha$ retained on GST-N-CoR beads in parallel. (E) Radiolabeled TR $\beta$ retained on GST-N-CoR and GST-GRIPI beads in parallel.

bound to the coactivator GRIP1 more strongly than NCoR, but did so with an identical ligand preference. Similar agonist-dependent interactions could be observed between ER $\beta$ and the alternate NR corepressor SMRT in vitro (Fig. 1C). Control binding experiments performed in parallel confirmed that ER $\alpha$ bound to N-CoR in the presence of SERMs, and not estradiol (Fig. 1D) and that TR $\beta$ bound $\mathrm{N}-\mathrm{CoR}$ in the absence of hormone, and was released in the presence of T3, whereas TR $\beta$ only bound GRIP1 in the presence of T3 (Fig. 1E).

To examine interactions between ER $\beta$ and N-CoR in mammalian cells we performed two-hybrid assays using a GAL4 DBD/N-CoR C-terminus fusion protein as bait and a VP16-ER $\beta$ LBD fusion as the prey. Fig. 2 shows that the ER $\beta$-LBD bound $\mathrm{N}-\mathrm{CoR}$ in the presence of agonists and phytoestrogens, but not SERMs. Control two-hybrid assays confirmed that a VP16-TR $\beta$ LBD fusion protein bound $\mathrm{N}-\mathrm{CoR}$ in the absence of hormone, but not in the presence of T3. E2 dependent binding of ER $\beta$ to N-CoR was dose dependent (Fig. 2B) with an EC50 (0.3 nM) that resembled that of ER $\beta$ binding to the GRIP1 NR box region (amino acids 610-770). Thus, ER $\beta$ binds the $\mathrm{N}$ CoR C-terminal NR interacting region in the presence of agonists, but not SERMs, and does so in vitro and in mammalian cells. Moreover, results from the two-hybrid assay indicate that the ER $\beta$ LBD is sufficient to obtain estrogendependent interactions with N-CoR.

\section{ER $\beta$ Interactions with $\mathrm{N}-\mathrm{CoR}$ are Dependent on AF-2 and require $\mathrm{HI} 2$}

Unliganded NRs usually bind ID motifs (consensus L/ IXXIIXXXL) in the N-CoR C-terminus. To ask whether ER $\beta$ might bind these motifs in the presence of estradiol, we examined the ability of peptides containing known NR interacting motifs to compete for the interaction (Fig. 3A). 
A
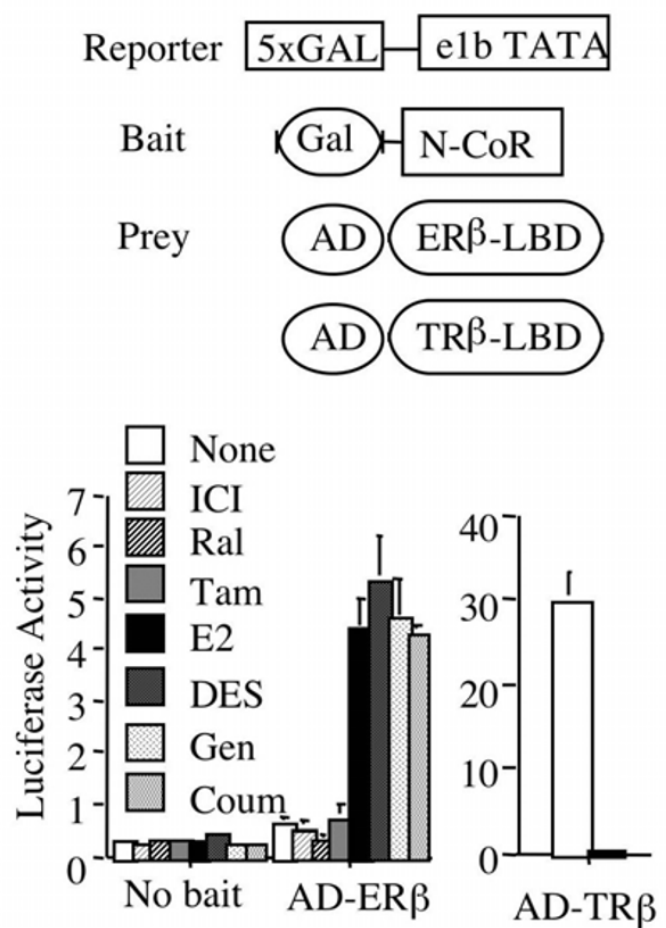

B

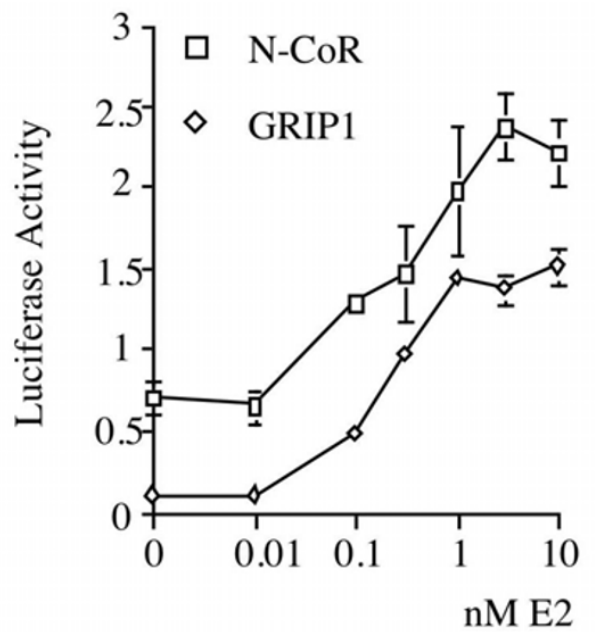

Figure 2

ER $\beta$ Binds N-CoR in the Presence of Agonists in Mammalian Cells. (A) Two-hybrid assays. Components of the twohybrid assay are shown in schematic at top. Results of a representative assay are shown below (with error bars representing the standard error of values determined from three separate wells). Ligand concentrations were: $\mathrm{ICl}$, raloxifene, Genistein, Coumestrol; I uM, Tamoxifen; 5 uM, estradiol DES 100 nM. (B) Estradiol dependence of ER $\beta$ interactions with N-CoR and GRIPI fusion proteins in mammalian cells. A representative experiment is shown. Error bars represent standard deviations from four wells.
A peptide overlapping to the N-CoR ID1 motif (amino acids 2265-2291) that competes for N-CoR binding to unliganded TR and RAR [16]failed to compete for agonistdependent ER $\beta$ interactions with N-CoR. By contrast, a peptide corresponding to GRIP1 NR box 2 did compete for this interaction $[40,41]$. This finding suggests that agonist-bound ER $\beta$ does not recognize ID motifs, and that ER $\beta$ interactions with $\mathrm{N}$-CoR more closely resemble those with GRIP1.

NR interactions with N-CoR are usually mediated by a hydrophobic cleft that spans residues from $\mathrm{H} 3$ and $\mathrm{H} 5$ and includes residues that lie under H12 in the liganded configuration [4,17]. These interactions are either independent of, or inhibited by, NR H12 [17,39,42]. By contrast, NR interactions with coactivators are mediated by residues from the upper part of $\mathrm{H} 3-\mathrm{H} 5$ and also require $\mathrm{H} 12$ itself [18]. Fig. 3B shows that a mutation in a conserved residue on $\mathrm{H} 12$ that is required for coactivator binding (E493K) abolished the interaction of ER $\beta$ with both N-CoR and GRIP1. Moreover, other mutations in the upper part of the H3-H5 region that comprises the AF-2 surface (D303Y, I310R and K314A on H3; V328R and L331R on H5) abolished ER $\beta$ interaction with both cofactors. Control mutations in other regions of the ER $\beta$ surface left its interactions with N-CoR and GRIP1 either slightly reduced or intact (these are L301R at the base of H3, V361R in the S-bends, M379R in H8; L426R, T434R in the H10 and Y488S in the H11-H12 loop). Thus, ER $\beta$ interactions with $\mathrm{N}-\mathrm{CoR}$ are dependent on the AF-2 surface (including H12) and, in this regard, resemble those of ER $\beta$ and GRIP1.

ER $\beta$ Binds an NR Box-Like Motif in the N-CoR C-terminus To map the region of N-CoR that interacted with ER $\beta$, we examined ER $\beta$ binding to a series of rationally designed smaller fragments of the N-CoR C-terminus (Fig. 4). ER $\beta$ did not bind two of these smaller fragments of N-CoR (1944-2033; 2230-2322) that contain known ID motifs (IDs 3 and 1 [16]). ER $\beta$ bound weakly to two regions of N-CoR (2033-2123; 2123-2230), one of which (20332123) contains an ID motif (ID2), but did so in a ligandindependent fashion. However, ER $\beta$ did bind to a fragment that spanned the extreme C-terminus (2322-2453) and did so in a manner that was promoted by E2 and suppressed by ICI, much like the interactions of ER $\beta$ with the entire N-CoR nuclear receptor interacting region.

The interaction of ER $\beta$ with the small N-CoR C-terminal fragment (amino acids 2322-2453) was stronger than that observed with the intact C-terminus (amino acids 1944-2453). This apparently improved binding is likely to be a consequence of our methodology (West et al. Unpublished data). In general, expression of large fragments of the N-CoR C-terminus in E. Coli yields a mix of 

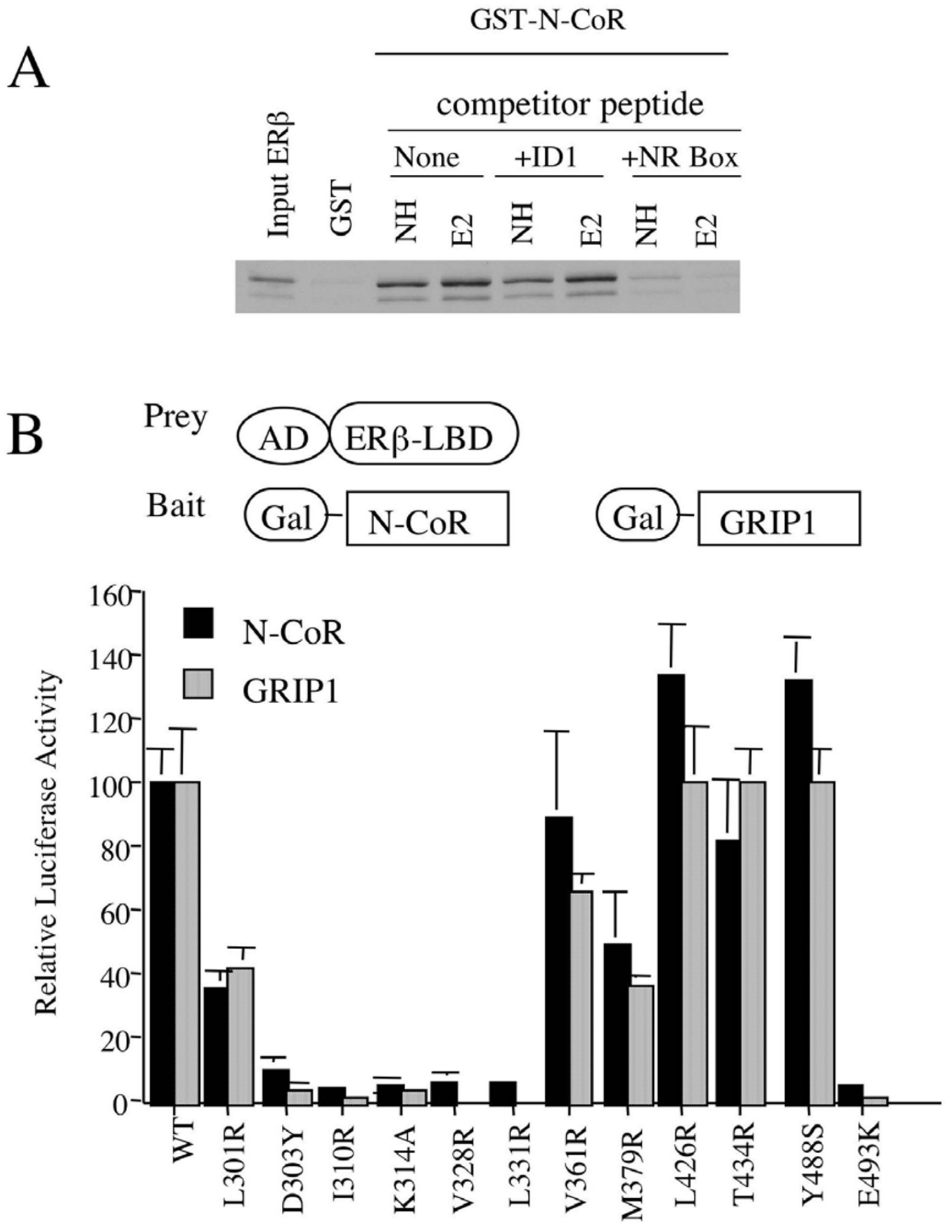

\section{Figure 3}

ER $\beta$ AF-2 is required for Corepressor and Coactivator Binding. (A) Peptide competition for ER $\beta$ binding to cofactors. Binding of ER $\beta$ to GST-N-CoR was assessed in the presence of $10 \mu \mathrm{g}$ of designated competitor peptide. (B) Binding of VPI6-ER $\beta$ LBD mutants to Gal-N-CoR and Gal-GRIPI was analyzed. Luciferase activity obtained with Gal-fusion and VPI6-ER $\beta$ in the presence of estradiol (100 nM) over four experiments was corrected for background and set to $100 \%$. Activity obtained with ER $\beta$ mutants was compared to this value. Standard errors are shown. 


\section{N-CoR C-Terminus}

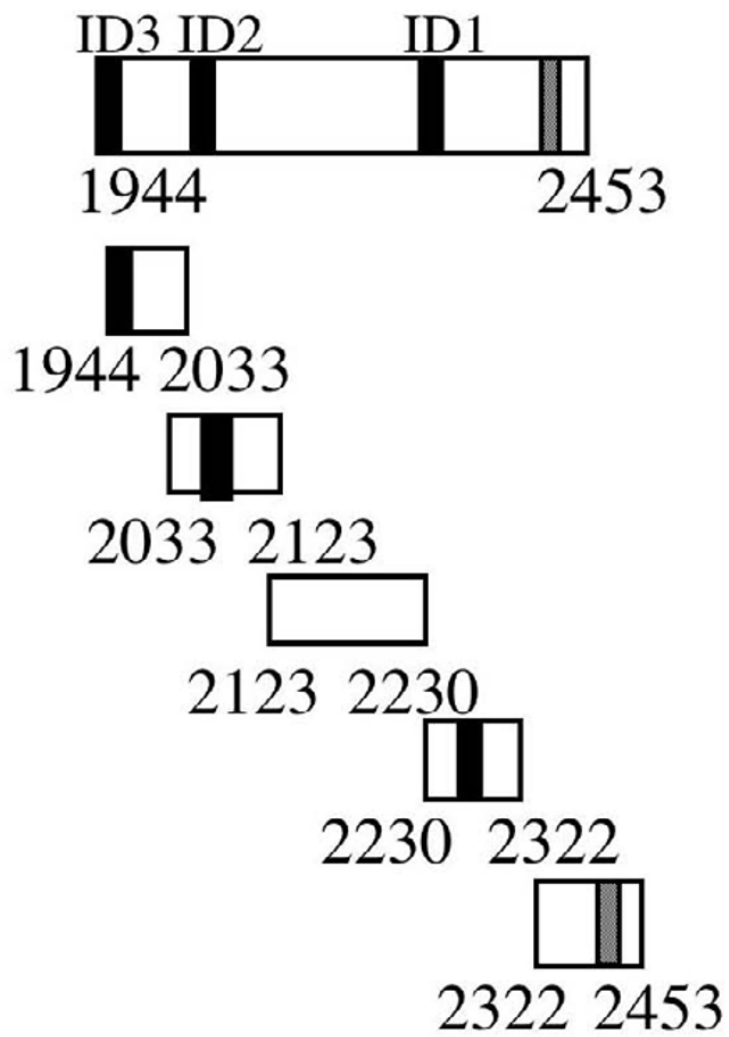

\section{Figure 4}

$E R \beta$ binds the N-CoR C-terminus. Binding of ER $\beta$ to short bacterially produced GST-N-CoR fragments was assessed as in Fig. IB. The approximate positions of N-CoR IDs are indicated with black bars, the putative ER $\beta$ interacting motif with a grey bar. Note that all of the binding experiments with shorter $\mathrm{N}$-CoR fragments were performed in parallel, and are compared to the same input ER $\beta$ protein ( $10 \%$ of total) displayed alongside the 1944-2033 fragment. A binding experiment that was performed in parallel utilizing the entire GST-N-CoR C-terminus (1944-2453) is shown for comparison at top. The likely reasons that ER $\beta$ binding to the shorter N-CoR fragment (2322-2453) is stronger than that obtained with the intact N-CoR C-terminus are discussed in the text.

full length protein along with truncated products. To create the expression vectors for the smaller fragments, truncated N-CoR polypeptides that were obtained in E. Coli extracts were subjected to protein sequence analysis and cDNA fragments that coded for the major truncated products were prepared. Each of the resulting polypep- tides was expressed very efficiently in E. Coli. The end product that was obtained after GST purification essentially consisted of a single short polypeptide as judged by Coomassie stain. Binding of ER $\beta$ to N-CoR (2322-2453) is probably very efficient for two reasons. First, equal amounts of GST fusion protein were used as baits for the 
translated ER $\beta$ protein in this series of experiments $(3 \mu \mathrm{g}$ per assay). Thus, N-CoR (2322-2453) is present in molar excess over N-CoR (1944-2453). Second, as developed above, preparations of N-CoR (1944-2453) generally contain truncated products, so sequences corresponding to the extreme N-CoR C-terminus (which binds ER $\beta$ ) is markedly under-represented. In any case, the fact that ER $\beta$ binds weakly or not at all to the three N-CoR ID motifs that mediate interactions with TRs and RARs and, instead, binds in an agonist-dependent fashion to a region in the C-terminus of N-CoR that has not previously been implicated in NR interactions indicates that ER $\beta$ recognizes a novel protein sequence motif within N-CoR.

The N-CoR C-terminus contains the sequence PLTIRMLS ( $\beta$-box, amino acids 2399-2406; Fig. 5). This sequence does not exactly conform to the LXXLL consensus, but contains features (underlined) that resemble the ER $\beta$ H12 region (LLLEML), and artificial ER $\beta$ interacting LXXLL peptides (293, PNLISLLS; D47, PLLLSLLS), both of which bind to the ER $\beta$ AF-2 surface [43-47]. Moreover, the presence of a proline residue amino-terminal to the hydrophobic groups is typical of so-called class II LXXLL motifs which are found in ER $\beta$ interacting cofactors such as TRAP220 and RIP140[45]. Finally, the unusual C-terminal hydrophobic pair (ML) has been observed in ER $\alpha$ and ER $\beta$ H12 [43,44,48], and in RIP140 NR boxes [19].

We investigated the significance of the $\beta$-box in ER $\beta$ interactions with N-CoR. As Fig. 6A shows, a synthetic $\beta$-box peptide competed for binding to N-CoR, albeit somewhat less efficiently than native GRIP1 NR box 2. Similar results were obtained in competition experiments that used GSTGRIP1 instead of GST-N-CoR (data not shown). The isolated $\beta$-box also acted as bait for a VP16-ER $\beta$ fusion protein in mammalian cells, and did so with similar efficiency to other known ER $\beta$ interacting peptides (Fig. 6B). Finally, mutations within the $\beta$-box (especially M2405A, L2406A) disrupted ER $\beta$ interactions with $N$ CoR in mammalian two-hybrid assays, but did not affect TR $\beta$ interactions (Fig. 6C). Thus, the $\beta$-box is sufficient to bind $\operatorname{ER} \beta$ and is essential for agonist-dependent ER $\beta$ interactions with the $\mathrm{N}$-CoR C-terminus.

Next, we examined whether the $\beta$-box would bind other NRs. The Gal- $\beta$-box fusion failed to recruit the ER $\alpha, \operatorname{TR} \beta$ or RAR $\beta$ LBDs in mammalian two-hybrid assays (Fig. 7A). Moreover, while the $\beta$-box and GRIP1 NR box 2 peptides both competed for ER $\beta$ interactions with GRIP1, only the NR box 2 peptide competed for ER $\alpha$ interactions with GRIP1 (Fig. 7B). Thus, the N-CoR $\beta$-box is, at least to some degree, ER $\beta$ specific. Mutation of N-CoR to obtain a $\beta$-box sequence that more closely resembled a conventional LXXLL motif (T2402L) led to enhanced hormonedependent interactions with $\operatorname{ER} \beta$ and permitted novel hormone-dependent interactions with ER $\alpha$ (Fig. 7C). Thus, some of the observed ER $\beta$ specificity is probably a consequence of an unexpected ability to tolerate the absence of a leucine residue at the $\mathrm{N}$-terminus of the LXXLL motif. Together, our results indicate that ER $\beta$ has the potential to utilize its AF-2 surface to bind NR boxes within coactivators or an NR box-like sequence in the $\mathrm{C}$ terminus of $\mathrm{N}-\mathrm{CoR}$.

\section{A HDAC Repressor Enhances ER $\beta$ Activity}

Since ER $\beta$ bound N-CoR and SMRT in the presence of estrogens, we investigated the possible involvement of corepressors in the actions of agonist-bound ER $\beta$ in vivo. To perform this experiment, we examined the effect of the HDAC inhibitor trichostatin A (TSA) on ER $\beta$ activity in transiently transfected HeLa cells. Fig. 8A confirms that $\mathrm{ER} \alpha$ shows stronger transcriptional activity than ER $\beta$ at a simple ERE responsive reporter gene. TSA enhanced the basal activity of the ERE-TK reporter gene by about fifteenfold in the absence of ER (see inset). However, TSA also equalized the relative transcriptional activity of both ERs. Fig. $8 \mathrm{~B}$ shows that the isolated $\mathrm{ER} \alpha \mathrm{LBD}$ exhibited more potent transcriptional activity than the ER $\beta$ LBD. However, both LBDs showed similar transcriptional activity in the presence of TSA. Thus, corepressor complex HDACs must play an unspecified role in restricting the transcriptional activity of both ER $\beta$ and, in particular, the ER $\beta$ LBD. This is consistent with the notion that corepressors restrict the activity of agonist-bound ER $\beta$-LBD.

\section{Conclusions}

NRs generally interact with the corepressors $\mathrm{N}-\mathrm{CoR}$ and SMRT either in the absence of ligand, or in the presence of receptor antagonists, and agonists promote corepressor release [4]. In this study, we demonstrated that ER $\beta$ binds to N-CoR in the presence of ER agonists such as estradiol and DES and the phytoestrogens genistein and coumestrol, but not in the presence of SERMs. Moreover, this interaction is dependent upon ER $\beta$ AF-2, including $\mathrm{H} 12$, and is competed by NR box peptides but not ID peptides. The hormone-dependent component of the ER $\beta$ /N-CoR interaction maps to the extreme C-terminus of N-CoR, which has not been previously implicated in NR interactions, and requires a sequence that resembles an ER $\beta$-specific NR box (PLTIRMLS, $\beta$-box). In this regard, ER $\beta$ differs from ER $\alpha$, which probably binds ID motifs in a SERMdependent fashion $[49,50]$ and shows reduced binding to $\mathrm{N}$-CoR in the presence of estradiol [39]. ER $\beta$ also differs from many other NRs, which either bind N-CoR in the absence of ligand and are released in the presence of ligand or interact with N-CoR in the presence of antagonists but not agonists [4].

The fact that the mode of ER $\beta$ interaction with N-CoR resembles that of NRs with coactivators [4], or with 


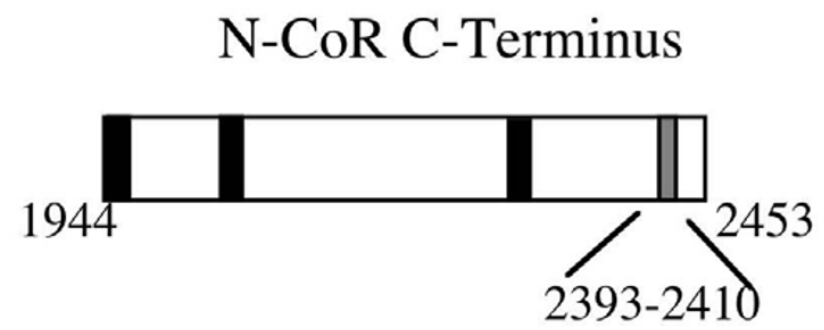

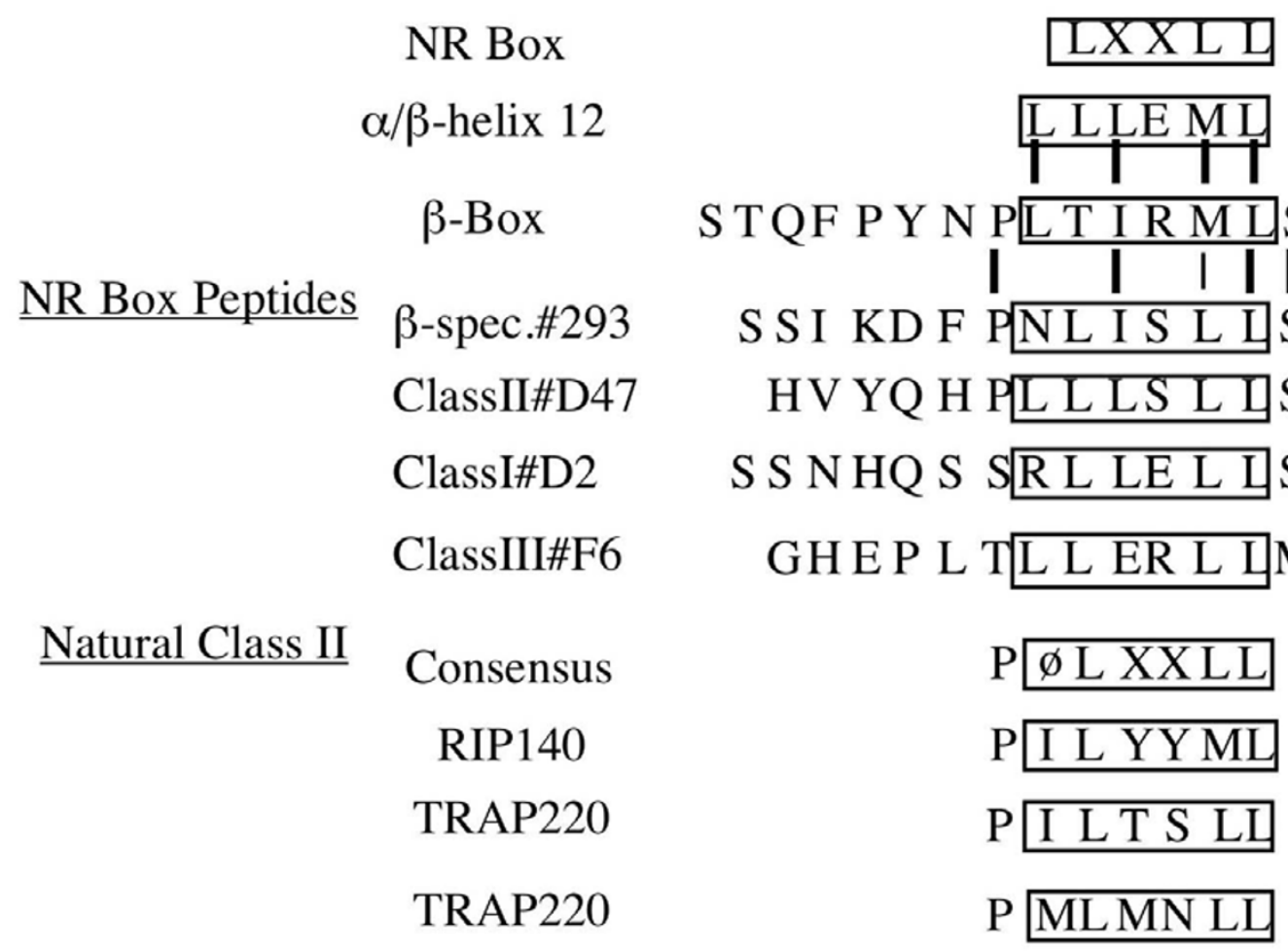

\section{Figure 5}

Sequence comparison of putative NR box-like motif ( $\beta$-box) with known ER AF-2 interacting peptides. Homologies between the $\beta$-box and ER $\beta$ HI2 or the artificial ER $\beta$ interacting peptide 293 are indicated with thick (homologous) or thin (conserved nature of side chain) lines.

corepressors that modulate the activity of liganded NR complexes, such as RIP140 [10], raises the possibility that ER $\beta$ may be able to recruit N-CoR and SMRT to estrogenregulated promoters in response to agonists and that the balance of overall ER $\beta$ activity in the presence of estrogens may be regulated by competition between p160s and corepressors for the same ER $\beta$ AF-2 surface. We recognize that our studies do not directly address this issue. Our attempts to identify ER $\beta$ mutants that differentiate between GRIP1 and N-CoR binding to analyze the role of agonist-dependent corepressor binding have not yet been successful (probably because ER $\beta$ utilizes the same surface to bind both cofactors). Moreover, transfection of N-CoR or various mutated N-CoR derivatives did not significantly affect ER $\beta$ activity at EREs or AP-1 sites (data not shown). We do not understand why, but in our hands, 
A

B

Bait

Gal peptide

Competitor Peptide:

$\beta$-Box

STQFPYNPLTIRMLSSTP

GRIP1 NR 2 KHKILHRLLQDSS

Trap

$\begin{array}{ll}\beta \text {-Box } & \text { STQFPYNPLTIRMLSSTP } \\ \text { GRIP1 NR 2 } & \text { KHKILHRLLQDSS }\end{array}$
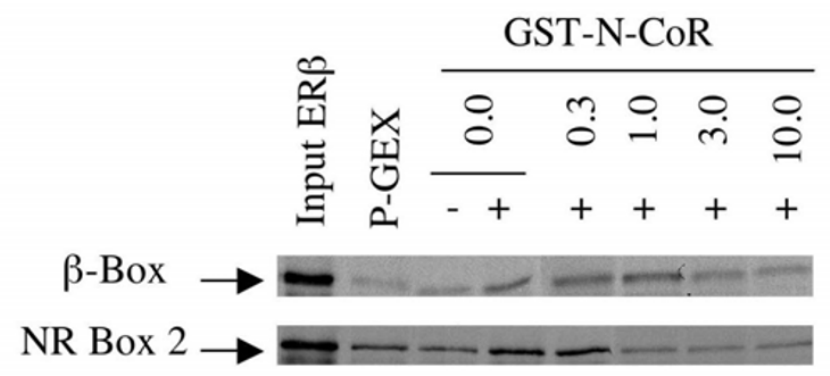

C

Prey
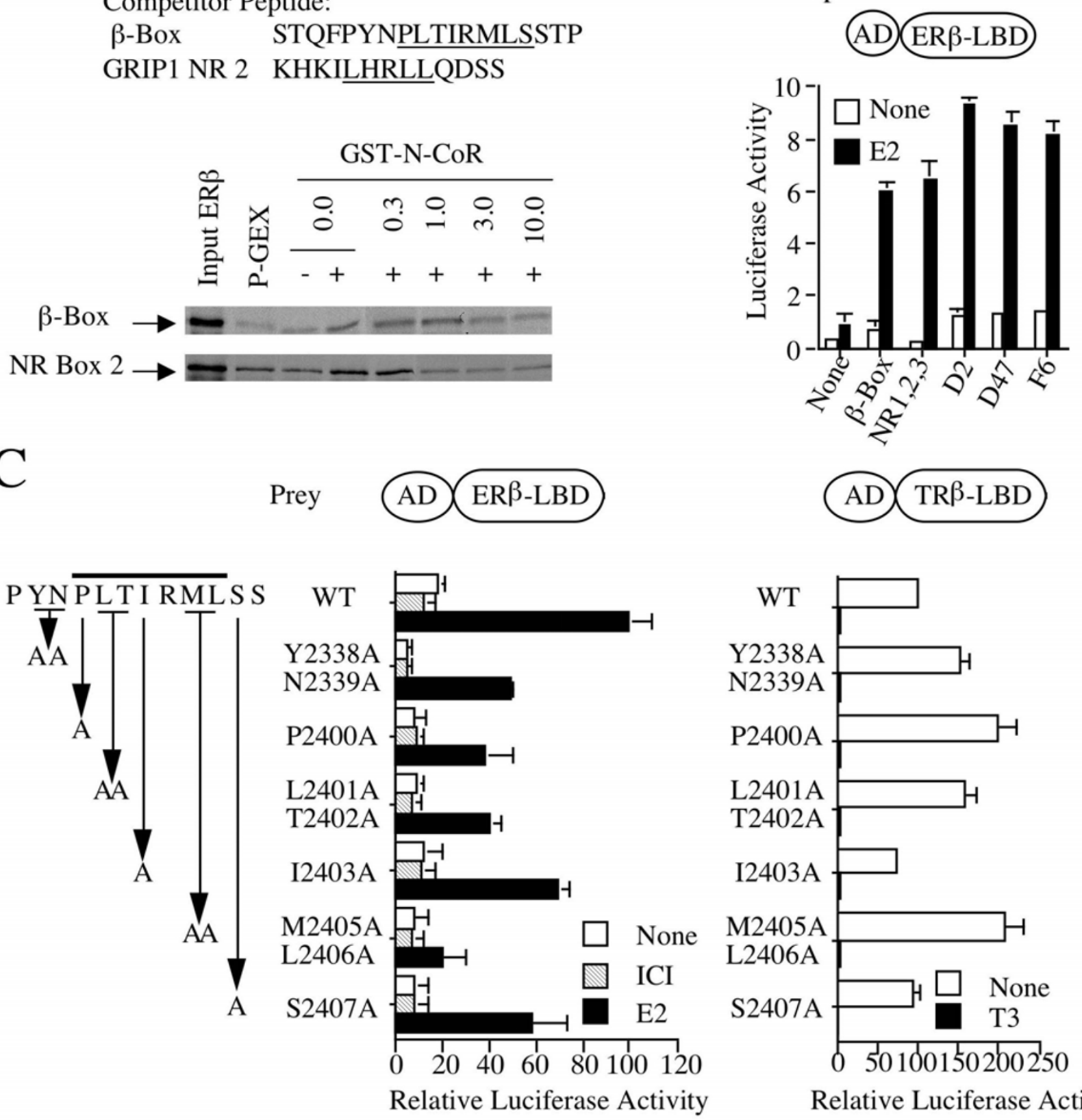

Relative Luciferase Activity

Figure 6

The N-CoR $\beta$-box binds ER $\beta$. (A) Peptide competitions. Binding of ER $\beta$ to either bacterially expressed GST-N-CoR (amino acids 2239-2453) was determined in the presence of increasing doses of competitor peptide (amounts shown at top refer to $\mu \mathrm{g}$ of peptide, plus signs refer to the presence of estradiol in the assay). (B) Interaction of ER $\beta$ with different peptides in mammalian two-hybrid assays. A representative experiment is shown. Errors are derived from three separate wells. (C) Analysis of ER $\beta$ interaction with mutant Gal-N-CoR fusion proteins. Values were determined as in Fig. 3. 
A
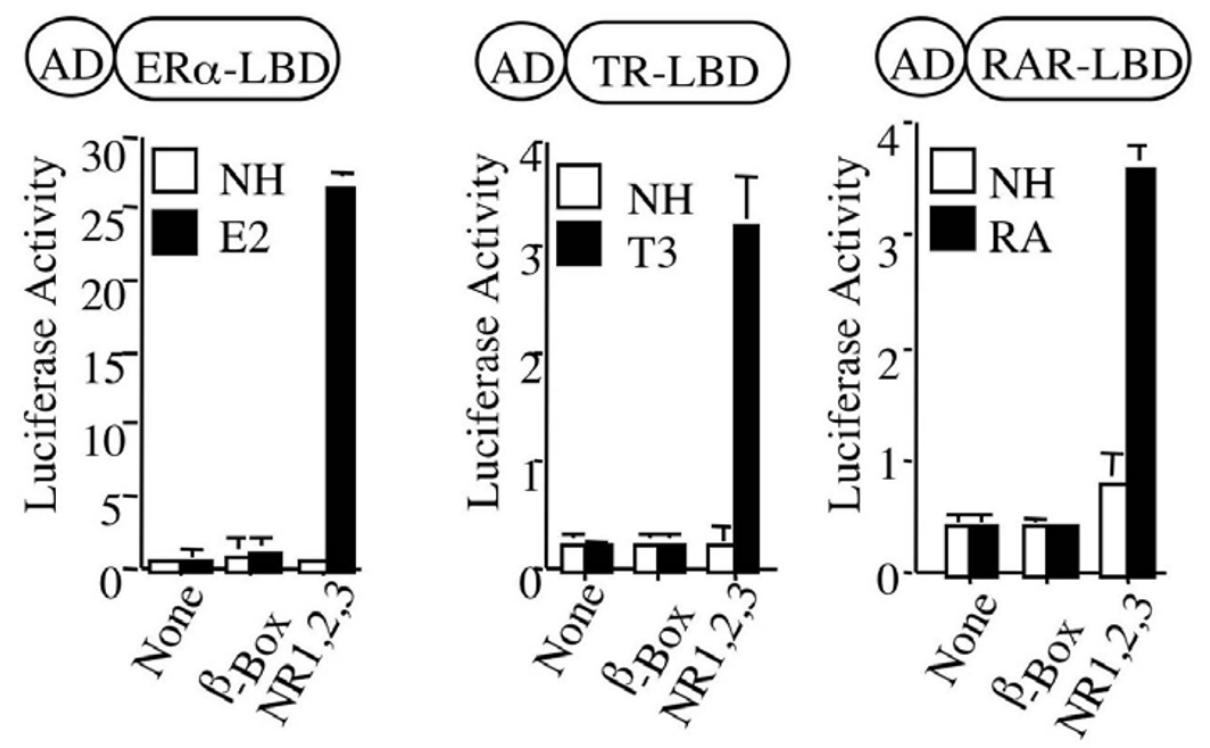

B
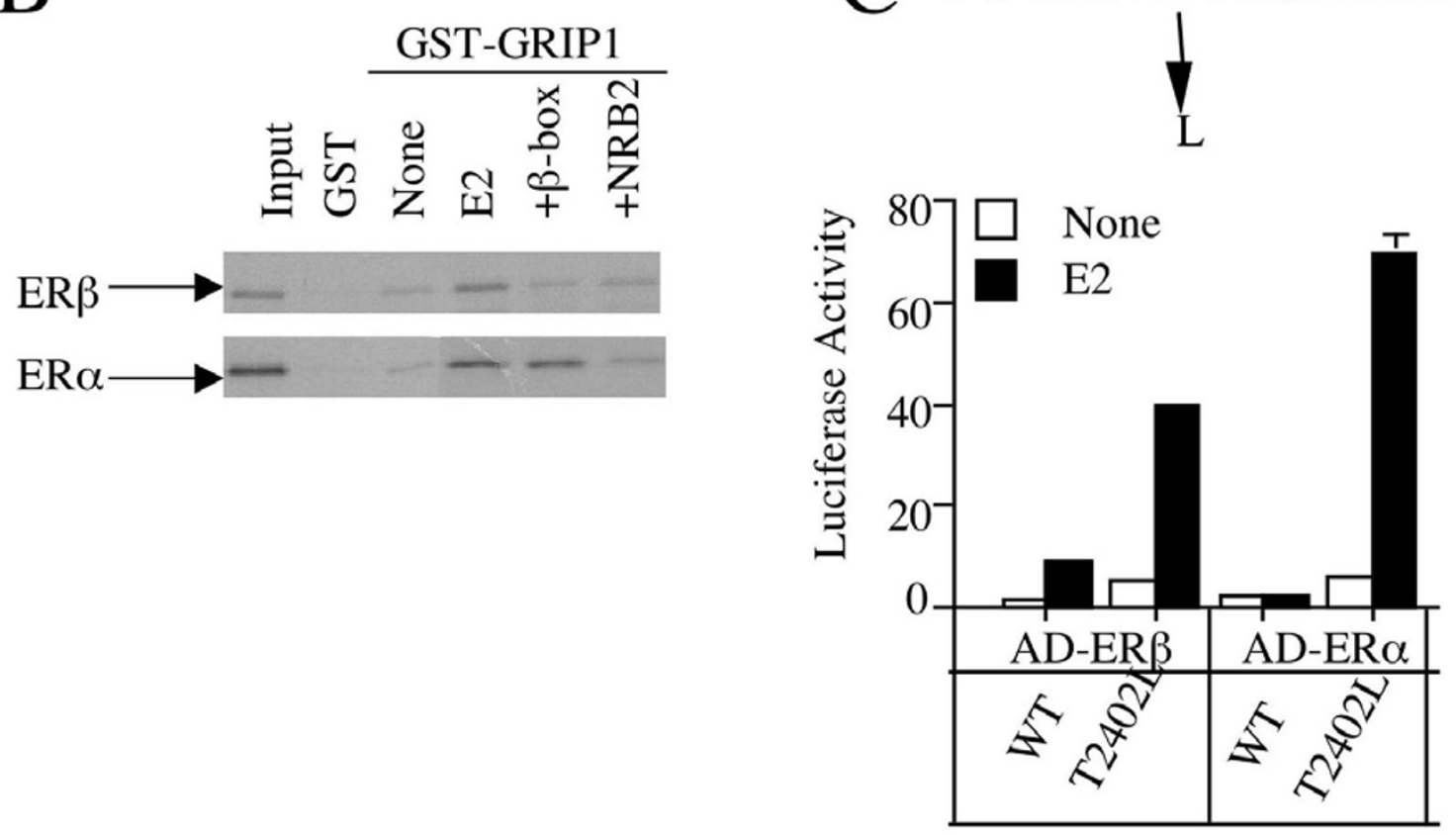

\section{Figure 7}

The $\beta$-box is an ER $\beta$-specific NR box. (A) Interactions of VPI6-NR fusions with the Gal- $\beta$-box fusion or a GAL-GRIPI (amino acids 610-770) control were determined in HeLa cell transfections. A representative experiment is shown. (B) Peptide competitions for ER $\alpha$ and ER $\beta$ binding to GST-GRIPI. Experiments utilized I0 $\mu$ g of competitor (C) Mutation of the $\beta$-box to resemble a consensus LXXLL motif. The panel shows the results of a mammalian two-hybrid assay in which binding of $\mathrm{Gal}-\mathrm{N}$ CoR or Gal-N-CoR T2402L to VPI6-ER $\beta$ or VPI6-ER $\alpha$ was assayed. 
A
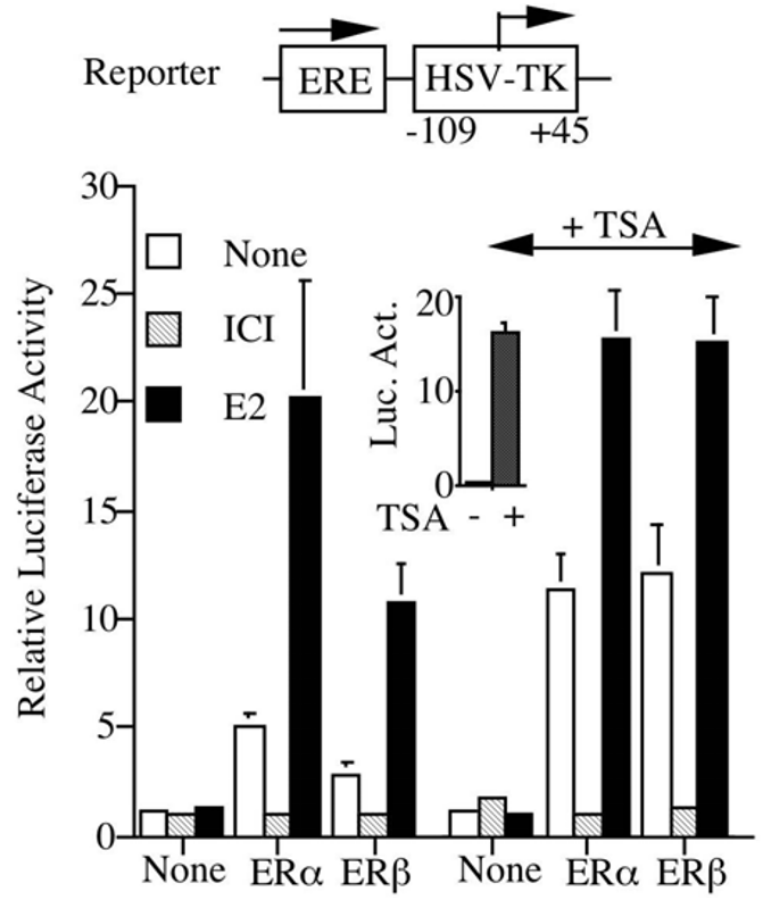

B

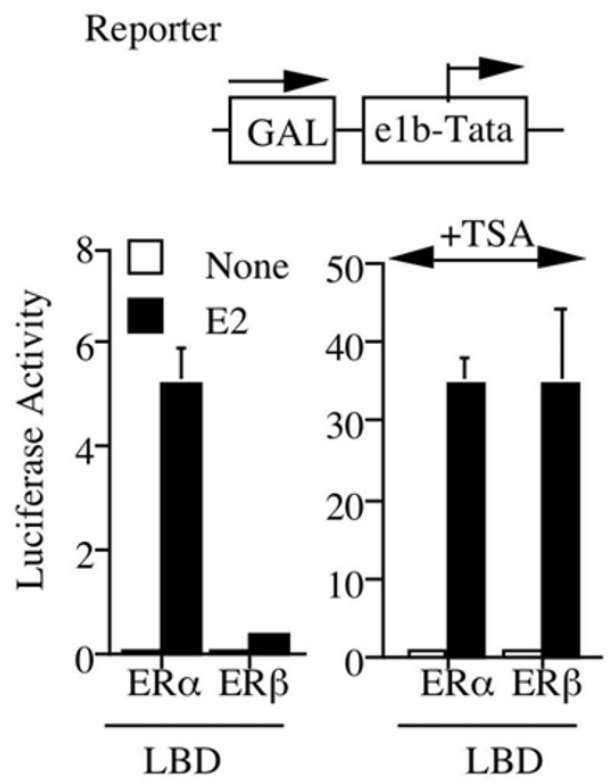

\section{Figure 8}

TSA Enhances ER $\beta$-LBD activity. (A) Results of a HeLa cell transfection in which ER $\alpha$ and ER $\beta$ activity was compared at a simple ERE responsive reporter gene. The value obtained in the absence of ER and ligand was set at I (irrespective of the presence or absence of TSA, $100 \mathrm{nM}$ ). Other values were calculated relative to this value. A single representative experiment is shown with errors derived from three wells. (B) Results of transfection in which ER $\alpha$ and ER $\beta$ LBD activities were compared in the absence (left) or presence (right) of TSA (I00 nM); note differences in scale. A single representative experiment is shown. Standard errors are derived from three wells.

transfected N-CoR also fails to affect TR or ER $\alpha$ activity (data not shown), despite the fact that it clearly interacts with both NRs. Nevertheless, we suspect that estrogendependent $\mathrm{N}$-CoR binding may represent an important component of the regulation of ER $\beta$ activity. As described in the Introduction, ER $\alpha$ and ER $\beta$ must interact differentially with factors that modulate ER activity in the presence of estrogens. The finding that estrogens suppress $\mathrm{N}$ CoR binding to ER $\alpha$ [39], but promote N-CoR binding to ER $\beta$ represents the first demonstration of a corepressor that shows completely distinct modes of hormonedependent interaction with the ER isoforms. Thus, N-CoR and SMRT and their associated HDACs are excellent candidates to explain some of the differential behaviors of the ER isoforms. Consistent with this notion, the apparent weak transcriptional activity of the ER $\beta$ LBD is a consequence of corepressor HDAC activity at some level (Fig.
$8)$. Full verification of the importance of ER $\beta$ interaction with $\mathrm{N}-\mathrm{CoR}$ will await demonstration that ER $\beta$ recruits $\mathrm{N}$ CoR and SMRT to estrogen-regulated promoters in vivo, and that this event is related to modulation of estrogen response.

While the ER isoforms have contrasting effects on AP-1 activity in the presence of estrogens, ER $\alpha$ truncations that lack the NTD and ER $\beta$ both enhance AP- 1 activity in the presence of SERMs [30,31]. Mutational analysis of ER $\alpha$ action at AP-1 sites suggests these effects may be related to $\mathrm{N}$-CoR binding [39], and we have proposed that SERM action at AP-1 sites may therefore involve contacts with corepressors [31,51]. The fact that ER $\alpha$ and ER $\beta$ show completely different ligand preferences of interaction with $\mathrm{N}$-CoR suggests that the target for SERM activation at AP1 sites may not be $\mathrm{N}$-CoR in both cases. Thus, this finding 
complicates our attempts to explain this unusual phenomenon. Perhaps the ER isoforms enhance AP-1 activity by superficially similar mechanisms that involve different cofactors. Alternatively, ER $\alpha$ and ER $\beta$ action at AP- 1 sites could, in fact, be mediated by SERM-dependent contacts with a common cofactor that is, as yet, unidentified. This common factor may yet prove to be N-CoR if ER $\beta$ interactions with the $\beta$-box were somehow masked in vivo.

What features of the $\beta$-box contribute to ER $\beta$ specificity? Intriguingly, the $\beta$-box contains $\mathrm{N}$-terminal proline and C-terminal serine residues that extend the homology of this region to an artificial ER $\beta$-specific peptide [45]. However, the $\beta$-box also lacks the first Leu of the consensus LXXLL. A mutation (PLTIRML $>$ PLLIRML) that restores the LXXLL consensus increases ER $\beta$ binding to N-CoR and permits $\mathrm{ER} \alpha$ to bind to $\mathrm{N}$-CoR in the presence of estrogens in mammalian two-hybrid assays. Thus, the unusual sequence of the $\beta$-box contributes to ER $\beta$ specificity and ER $\beta$ can tolerate the absence of a conserved N-terminal leucine in LXXLL motifs. ER $\beta$ might bind to yet more cofactors that contain variant NR boxes that resemble the $\beta$-box. Other aspects of ER $\beta$ interactions with corepressors warrant further study. It will be interesting to understand whether the weaker ER $\beta$ interactions with other regions of $\mathrm{N}$-CoR (which are insensitive to ICI) play a role in ER $\beta$ binding (Fig. 4). Finally, SMRT also binds ER $\beta$ in the presence of estrogens, but we have not explored the structural features that promote this interaction. Intriguingly, human SMRT contains a sequence insertion at the position of the hydrophobic pair in the N-CoR $\beta$-box, which apparently leads to deletion of both residues ( $\mathrm{N}-\mathrm{CoR} /$ RMLS $>$ SMRT/RLqagvmaS) [52]. Perhaps SMRT contains a different NR interacting motif or the N-CoR NR box sequence may be more complex than we have initially reported here.

\section{Methods \\ Materials}

Estradiol, diethylstilbestrol (DES), tamoxifen, genistein, coumestrol, thyroid hormone, retinoic acid and trichostatin A (TSA) were purchased from Sigma (St. Louis, MO). ICI 182,780 was a gift from Alan Wakeling (Astra/Zeneca Pharmaceuticals, Macclesfield UK). Raloxifene was a gift from Stefan Nilsson (KaroBio AB, Huddinge, Sweden). Peptides were synthesized at the Biomolecular Resource Center at UCSF.

The following plasmids (pSG5-ER $\alpha$, pSG5-ER $\beta$ (amino acids 1-530) [31], pGEX-N-CoR and pGEX-SMRT[39], VP16-TR $\beta$ and Gal-N-CoR[16], GST-N-CoR fusions[17], ERE-LUC, GK1/Gal4 responsive reporter and Gal-ER $\alpha$ LBD [53], pM-D2, pM-D47, pM-F6 [46]) have been previously described. VP16-ER $\beta$ LBD and Gal-ER $\beta$ LBD contain human ER $\beta$ sequences and were gifts from Dr. Dale
Leitmann (University of California, San Francisco). VP16RAR-LBD was a gift from Dr. David Moore, Baylor, Houston, Texas. Gal-GRIP1 NR box $(1,2,3)$ fusion (amino acids 610-770) was prepared by PCR amplification of the appropriate region of GRIP1 (primers obtained from Biomolecular Resource Center, UCSF) containing EcoRI and SalI sites, the PCR fragment was digested with these enzymes and subcloned into the pM GAL4 expression vector (Clontech Laboratories, Inc. Palo Alto, CA). VP16-ER $\beta$ mutations and Gal-N-CoR mutations were prepared using standard PCR-based site directed mutagenesis (Quickchange Kit, Stratagene, La Jolla, CA) and confirmed by sequencing. The GAL4- $\beta$ box fusion was prepared by synthesizing oligonucleotides corresponding to the $\beta$-box sequence with engineered EcoRI and SalI restriction sites. Annealed and phosphorylated double stranded oligonucleotide was subcloned into the appropriate sites in the $\mathrm{PM}$ vector.

\section{Bacterial Protein Expression and GST Pulldown Assays}

GST-fusions were expressed in E. Coli BL21 [28]. Cultures were grown to OD600 1.5 at room temperatures (approximately $22^{\circ} \mathrm{C}$ ) and protein production was initiated by addition of IPTG to $1 \mathrm{mM}$. After four hours, bacterial pellets were obtained, resuspended in $20 \mathrm{mM}$ HEPES pH 7.9/ $80 \mathrm{mM} \mathrm{KCl} / 6 \mathrm{mM} \mathrm{MgCl} / 2 \mathrm{mM}$ Dithiothreitol/1 mM ATP/0.2 mM phenylmethylsulfonyl fluoride and protease inhibitors and sonicated. Debris was pelleted by centrifugation in an ss34 rotor for 1 hour at 12,000 rpm. The supernatant was incubated with glutathione sepharose $4 \mathrm{~B}$ beads (Amersham Pharmacia Biotech AB, Uppsala, Sweden) and washed as previously described. Protein preparations were stored at $-20^{\circ} \mathrm{C}$ in $20 \%$ glycerol.

Labeled ERs were produced using coupled in vitro transcription-translation (TNT kit, Promega, Madison, Wisconsin). Assays were carried out in a volume of $150 \mu$ l that contained $137.5 \mu \mathrm{l}$ of ice-cold protein binding buffer (PBB) along with $10 \mu$ l of GST-bead slurry corresponding to $3 \mu \mathrm{g}$ of fusion protein, $1 \mu \mathrm{l}$ of in vitro translated protein and $1.5 \mu \mathrm{l}$ of ligand or vehicle and/or peptides or vehicle. PBB was freshly prepared in $24 \mathrm{ml}$ aliquots composed of $20 \mathrm{ml} \mathrm{A}-150$ (20 mM Hepes, $150 \mathrm{mM} \mathrm{KCl}, 10 \mathrm{mM} \mathrm{MgCl} 2$ and $1 \%$ glycerol), and $2 \mathrm{ml}$ each of phosphate buffered saline supplemented, respectively, with $1 \%$ Triton X-100 and $1 \%$ NP-40. PMSF, DTT, BSA and protease inhibitor cocktail (Novagen) were added to $0.1 \mathrm{mM}, 1 \mathrm{mM}, 2 \mu \mathrm{g} / \mathrm{ml}$ and $1 / 1000$ dilution respectively. The mix was incubated for two hours in the cold room with gentle agitation, the beads were pelleted by spinning briefly on a bench top Eppendorf centrifuge, washed four times with PBB containing no BSA, and the pellet was dried under vacuum for twenty minutes. Labeled protein was subjected to SDSpolyacrylamide gel electrophoresis and autoradiography. 


\section{Transfections}

HeLa cells were grown in DME/F-12 Ham's 1:1 mix, without phenol red (Sigma) containing 10\% iron supplemented calf serum (Sigma) and pen-strep. Cells were transfected by electroporation [28]. Transfections contained $2 \mu \mathrm{g}$ of luciferase and actin- $\beta$-galactosidase reporters and, where indicated, $1 \mu \mathrm{g}$ of ER, VP16-fusion protein or GAL4-fusion protein expression vectors or empty vector controls. Luciferase and $\beta$-galactosidase activities were measured using luciferase (Promega, Madison, WI) and Galacto-Light assay systems (Tropix, Bedford, MA).

\section{List of Abbreviations}

AIB1 Amplified in breast cancer 1 .

AF-1 Activation function 1

AF-2 Activation function 2

AP-1 Activator protein 1

CARM1 Coactivator associated arginine methyl-transferase 1 .

CBP CREB binding protein.

CRE Cyclic Amp response element

DAX Dosage sensitive sex reversal adrenal hyperplasia congenital critical region on the X-chromosome, region 1.

DES Diethylstilbestrol

DNA Deoxyribonucleic acid

DBD DNA binding domain

TNF $\alpha$ Tumor necrosis factor alpha 1

E2 Estradiol

ER $\alpha$ Estrogen receptor alpha

ER $\beta$ Estrogen receptor beta

ERE, Estrogen response element

GRIP1 Glucocorticoid receptor interacting protein 1;

GST Glutathione S-transferase

H Helix

HAT Histone acetyl-transferase
HET-SAFB Hsp27-ERE-TATA binding protein/scaffold attachment factor B.

HDAC Histone de-acetylase

ID Interaction domain.

LBD Ligand binding domain

NR Nuclear receptor

NTD Amino terminal domain

$\mathrm{N}$-CoR Nuclear receptor corepressor

PBS Phosphate buffered saline

PCR Polymerase chain reaction

PERC PGC-1 related estrogen receptor coactivator

PGC-1 Peroxisome proliferator activated receptor gamma coactivator 1 .

RAR Retinoic acid receptor

REA Repressor of estrogen receptor activity

RIP140 Receptor interacting protein of $140 \mathrm{Kd}$

SDS-PAGE Sodium dodecyl sulfate polyacrylamide gel electrophoresis

SMRT Silencing Mediator of Retinoid and Thyroid Responsive transcription.

SERM Selective estrogen receptor modulator(s)

SHP Short heterodimer partner

SRC-1 Steroid receptor coactivator 1

TR Thyroid receptor

TRAP220 TR associated protein of $200 \mathrm{Kd}$.

\section{Competing Interests}

PW None declared.

CV None declared

PN None declared

RHP Jr. None declared. 
AM Since the studies were performed, has moved to Plexxikon, a company with interests in protein structure.

BLW Since the studies were performed, has moved to Plexxikon, a company with interests in protein structure.

JDB has proprietary interests in, and serves as consultant and deputy director to Karo Bio AB, a Swedish company that develops pharmaceuticals that target NRs.

PJK has significant financial interests in, and is a consultant and former director of, Karo Bio $\mathrm{AB}$.

\section{Authors Contributions}

PW Conceived and directed the studies, wrote the paper, performed plasmid constructions and transfection studies.

CV Performed transfection, mutagenesis and GST pulldown experiments under guidance of PW.

PN Performed transfection, mutagenesis and GST pulldown experiments under guidance of PW.

RHP Jr. Provided intellectual input in the study design.

AM. Expressed GST N-CoR fragments for pulldown studies with ER $\beta$.

BW Designed bacterial expression vectors for N-CoR fragments, cloned cDNA fragments for GST-N-CoR expression vectors and provided intellectual input into the study design.

JDB. Directed studies of NR interactions with N-CoR and provided intellectual input into study design.

PJK. Co-directed studies along with PW and provided intellectual input into study design.

All authors read and approved the final manuscript.

\section{Acknowledgements}

This work was supported by NIH grants to PJK (DK5I 083 and CA802I0) and JDB (DK5|28I).

\section{References}

I. Ribeiro RCJ, Kushner PJ and Baxter JD: The nuclear hormone receptor gene superfamily Annu Rev Med 1995, 46:443-453.

2. Weatherman RV, Fletterick RJ and Scanlan TS: Nuclear-receptor ligands and ligand-binding domains Annu Rev Biochem 1999, 68:559-581.

3. McKenna NJ and O'Malley BW: Nuclear receptors, coregulators, ligands, and selective receptor modulators: making sense of the patchwork quilt Ann N Y Acad Sci 200I, 949:3-5.

4. Glass CK and Rosenfeld MG: The coregulator exchange in transcriptional functions of nuclear receptors Genes Dev 2000, |4:|2|-|4|.
5. Glass CK, Rose DW and Rosenfeld MG: Nuclear receptor coactivators Curr Opin Cell Biol 1997, 9:222-232.

6. Chen D, Ma H, Hong H, Koh SS, Huang SM, Schurter BT, Aswad DW and Stallcup MR: Regulation of transcription by a protein methyltransferase Science 1999, 284:2174-2177.

7. Ito M, Yuan CX, Okano HJ, Darnell RB and Roeder RG: Involvement of the TRAP220 component of the TRAP/SMCC coactivator complex in embryonic development and thyroid hormone action $\mathrm{Mol}$ Cell 2000, 5:683-693.

8. Puigserver P, Wu Z, Park CW, Graves R, Wright M and Spiegelman BM: A cold-inducible coactivator of nuclear receptors linked to adaptive thermogenesis Cell 1998, 92:829-839.

9. Knutti $D$ and Kralli A: PGC-I, a versatile coactivator Trends Endocrinol Metab 200I, I 2:360-365.

10. Cavailles V, Dauvois S, L'Horset F, Lopez G, Hoare S, Kushner PJ and Parker MG: Nuclear factor RIPI 40 modulates transcriptional activation by the estrogen receptor Embo J 1995, I4:374I-375I.

II. Moraitis AN, Giguere V and Thompson CC: Novel mechanism of nuclear receptor corepressor interaction dictated by activation function 2 helix determinants $\mathrm{Mol}$ Cell Biol 2002, 22:683I6841 .

12. Seol W, Choi HS and Moore DD: An orphan nuclear hormone receptor that lacks a DNA binding domain and heterodimerizes with other receptors Science 1996, 272:1336-1339.

13. Zhang $H$, Thomsen JS, Johansson L, Gustafsson JA and Treuter E: DAX-I functions as an LXXLL-containing corepressor for activated estrogen receptors J Biol Chem 2000, 275:39855-39859.

14. Montano MM, Ekena K, Delage-Mourroux R, Chang W, Martini P and Katzenellenbogen BS: An estrogen receptor-selective coregulator that potentiates the effectiveness of antiestrogens and represses the activity of estrogens Proc Natl Acad Sci U S A 1999, 96:6947-6952.

15. Oesterreich S, Zhang Q, Hopp T, Fuqua SA, Michaelis M, Zhao HH, Davie JR, Osborne CK and Lee AV: Tamoxifen-bound estrogen receptor (ER) strongly interacts with the nuclear matrix protein HET/SAF-B, a novel inhibitor of ER-mediated transactivation Mol Endocrinol 2000, 14:369-38I.

16. Webb P, Anderson CM, Valentine C, Nguyen P, Marimuthu A, West $B L$, Baxter JD and Kushner PJ: The nuclear receptor corepressor (N-CoR) contains three isoleucine motifs (I/LXXII) that serve as receptor interaction domains (IDs) Mol Endocrinol 2000, 14:1976-1985.

17. Marimuthu A, Feng W, Tagami T, Nguyen H, Jameson JL, Fletterick RJ, Baxter JD and West BL: TR surfaces and conformations required to bind nuclear receptor corepressor Mol Endocrinol 2002, 16:27I-286.

18. Feng W, Ribeiro RC, Wagner RL, Nguyen H, Apriletti JW, Fletterick RJ, Baxter JD, Kushner PJ and West BL: Hormone-dependent coactivator binding to a hydrophobic cleft on nuclear receptors Science 1998, 280:1747-1749.

19. Heery DM, Kalkhoven E, Hoare S and Parker MG: A signature motif in transcriptional co-activators mediates binding to nuclear receptors Nature 1997, 387:733-736.

20. Parker MG: Transcriptional activation by oestrogen receptors Biochem Soc Symp 1998, 63:45-50.

21. Katzenellenbogen BS, Montano MM, Ediger TR, Sun J, Ekena K, Lazennec G, Martini PG, Mclnerney EM, Delage-Mourroux R, Weis $K$ and Katzenellenbogen JA: Estrogen receptors: selective ligands, partners, and distinctive pharmacology Recent Prog Horm Res 2000, 55:163-193.

22. Couse JE, Mahato D, Eddy EM and Korach KS: Molecular mechanism of estrogen action in the male: insights from the estrogen receptor null mice Reprod Fertil Dev 200I, I3:2I I-219.

23. Pettersson K and Gustafsson JA: Role of estrogen receptor beta in estrogen action Annu Rev Physiol 200I, 63:165-192.

24. Kuiper GG, Lemmen JG, Carlsson B, Corton JC, Safe SH, van der Saag PT, van der Burg B and Gustafsson JA: Interaction of estrogenic chemicals and phytoestrogens with estrogen receptor beta Endocrinology 1998, 139:4252-4263.

25. Hall JM and McDonnell DP: The estrogen receptor beta-isoform (ERbeta) of the human estrogen receptor modulates ERalpha transcriptional activity and is a key regulator of the cellular response to estrogens and antiestrogens Endocrinology 1999, 140:5566-5578. 
26. Pettersson K, Delaunay F and Gustafsson JA: Estrogen receptor beta acts as a dominant regulator of estrogen signaling Oncogene 2000, I 9:4970-4978.

27. An J, Ribeiro RC, Webb P, Gustafsson JA, Kushner PJ, Baxter JD and Leitman DC: Estradiol repression of tumor necrosis factoralpha transcription requires estrogen receptor activation function-2 and is enhanced by coactivators Proc Natl Acad Sci U SA 1999, 96:15161-15166.

28. Webb P, Lopez GN, Uht RM and Kushner PJ: Tamoxifen activation of the estrogen receptor/AP-I pathway: potential origin for the cell-specific estrogen-like effects of antiestrogens $\mathrm{Mol}$ Endocrinol 1995, 9:443-456.

29. Liu MM, Albanese C, Anderson CM, Hilty K, Webb P, Uht RM, Price RH Jr, Pestell RG and Kushner PJ: Opposing action of estrogen receptors alpha and beta on cyclin DI gene expression J Biol Chem 2002, 277:24353-24360.

30. Paech K, Webb P, Kuiper GG, Nilsson S, Gustafsson J, Kushner PJ and Scanlan TS: Differential ligand activation of estrogen receptors ERalpha and ERbeta at API sites Science I997, 277:I508I5I0.

31. Webb P, Nguyen P, Valentine C, Lopez GN, Kwok GR, Mclnerney E, Katzenellenbogen BS, Enmark E, Gustafsson JA, Nilsson S and Kushner PJ: The estrogen receptor enhances AP-I activity by two distinct mechanisms with different requirements for receptor transactivation functions Mol Endocrinol 1999, I3:1672-1685.

32. Weatherman RV and Scanlan TS: Unique protein determinants of the subtype-selective ligand responses of the estrogen receptors (ERalpha and ERbeta) at AP-I sites J Biol Chem $200 \mathrm{I}$, 276:3827-3832

33. Tremblay GB, Tremblay A, Labrie F and Giguere V: Dominant activity of activation function I (AF-I) and differential stoichiometric requirements for AF-I and -2 in the estrogen receptor alpha-beta heterodimeric complex Mol Cell Biol 1999, 19:1919-1927.

34. McDonnell DP, Chang CY and Norris JD: Development of peptide antagonists that target estrogen receptor-cofactor interactions / Steroid Biochem Mol Biol 2000, 74:327-335.

35. Norris JD, Chang C and McDonnell DP: Estrogen receptor-cofactor interactions as targets for novel drug discovery Ernst Schering Res Found Workshop 200I:I8I-20I.

36. Tremblay GB and Giguere V: Coregulators of estrogen receptor action Crit Rev Eukaryot Gene Expr 2002, I 2: I-22.

37. Seol W, Hanstein B, Brown M and Moore DD: Inhibition of estrogen receptor action by the orphan receptor SHP (short heterodimer partner) Mol Endocrinol 1998, I 2:I55 I-I557.

38. Kressler D, Schreiber SN, Knutti D and Kralli A: The PGC-Irelated protein PERC is a selective coactivator of estrogen receptor alpha J Biol Chem 2002, 277:| 39|8-I3925.

39. Webb P, Nguyen P and Kushner PJ: Differential SERM effects on corepressor binding dictate ER alpha activity in vivo J Biol Chem 2002.

40. Ding XF, Anderson CM, Ma H, Hong H, Uht RM, Kushner PJ and Stallcup MR: Nuclear receptor-binding sites of coactivators glucocorticoid receptor interacting protein I (GRIPI) and steroid receptor coactivator I (SRC-I): multiple motifs with different binding specificities Mol Endocrinol I998, I 2:302-3 I3.

4I. Darimont BD, Wagner RL, Apriletti JW, Stallcup MR, Kushner PJ, Baxter JD, Fletterick RJ and Yamamoto KR: Structure and specificity of nuclear receptor-coactivator interactions Genes Dev 1998, I 2:3343-3356

42. Zhang J, Hu X and Lazar MA: A novel role for helix 12 of retinoid $X$ receptor in regulating repression Mol Cell Biol 1999, 19:64486457.

43. Brzozowski AM, Pike AC, Dauter Z, Hubbard RE, Bonn T, Engstrom O, Ohman L, Greene GL, Gustafsson JA and Carlquist M: Molecular basis of agonism and antagonism in the oestrogen receptor Nature 1997, 389:753-758.

44. Shiau AK, Barstad D, Loria PM, Cheng L, Kushner PJ, Agard DA and Greene GL: The structural basis of estrogen receptor/coactivator recognition and the antagonism of this interaction by tamoxifen Cell 1998, 95:927-937.

45. Chang C, Norris JD, Gron H, Paige LA, Hamilton PT, Kenan DJ, Fowlkes D and McDonnell DP: Dissection of the LXXLL nuclear receptor-coactivator interaction motif using combinatorial peptide libraries: discovery of peptide antagonists of estrogen receptors alpha and beta Mol Cell Biol 1999, 19:8226-8239.
46. Norris JD, Paige LA, Christensen DJ, Chang CY, Huacani MR, Fan D, Hamilton PT, Fowlkes DM and McDonnell DP: Peptide antagonists of the human estrogen receptor Science 1999, 285:744-746.

47. Paige LA, Christensen DJ, Gron H, Norris JD, Gottlin EB, Padilla KM, Chang CY, Ballas LM, Hamilton PT, McDonnell DP and Fowlkes DM: Estrogen receptor (ER) modulators each induce distinct conformational changes in ER alpha and ER beta Proc Natl Acad Sci U S A 1999, 96:3999-4004.

48. Pike AC, Brzozowski AM, Hubbard RE, Bonn T, Thorsell AG, Engstrom O, Ljunggren J, Gustafsson JA and Carlquist M: Structure of the ligand-binding domain of oestrogen receptor beta in the presence of a partial agonist and a full antagonist Embo J 1999, I 8:4608-46 I8.

49. Shang $Y, H_{u} X$, DiRenzo J, Lazar MA and Brown M: Cofactor dynamics and sufficiency in estrogen receptor-regulated transcription Cell 2000, I 03:843-852.

50. Norris JD, Fan D, Sherk A and McDonnell DP: A negative coregulator for the human ER Mol Endocrinol 2002, 16:459-468.

51. Kushner PJ, Agard DA, Greene GL, Scanlan TS, Shiau AK, Uht RM and Webb P: Estrogen receptor pathways to AP-I J Steroid Biochem Mol Biol 2000, 74:311-317.

52. Ordentlich P, Downes M, Xie W, Genin A, Spinner NB and Evans RM: Unique forms of human and mouse nuclear receptor corepressor SMRT Proc Natl Acad Sci U S A 1999, 96:2639-2644.

53. Webb P, Nguyen P, Shinsako J, Anderson C, Feng W, Nguyen MP, Chen D, Huang SM, Subramanian S, McKinerney E, Katzenellenbogen $B S$, Stallcup MR and Kushner PJ: Estrogen receptor activation function I works by binding p 160 coactivator proteins $\mathrm{Mol}$ Endocrinol 1998, 12:1605-1618.
Publish with Bio Med Central and every scientist can read your work free of charge

"BioMed Central will be the most significant development for disseminating the results of biomedical research in our lifetime. "

Sir Paul Nurse, Cancer Research UK

Your research papers will be:

- available free of charge to the entire biomedical community

- peer reviewed and published immediately upon acceptance

- cited in PubMed and archived on PubMed Central

- yours - you keep the copyright

Submit your manuscript here:

http://www.biomedcentral.com/info/publishing_adv.asp
BioMedcentral 